\title{
Religious and Cultural Manipulation of Gender Roles in The Bull and the She Devil by Zeb Un Nisa Hameedullah
}

\author{
*Dr. Amna Saeed \\ ***Azan Khalid \\ *** Dr. Syed Shujaat Ali
}

\section{ABSTRACT:}

This paper attempts to study the exploitation of women that takes place in the rural areas of Pakistan in the name of cultural and religious norms. Its main focus is to do analysis of Zeb Un Nisa Hameedullah's short story titled The Bull and the She Devil under the Lacanian psychoanalytic model delimited to the Mirror stage. The Mirror stage speculates that an individual recognizes himself in the mirror literally and figuratively. In the short story, Ghulam Qadir, the main character, sees himself in the mirror of his newlywed wife and recognizes his weakness. He projects his weaknesses that mainly surface up after his marriage. He does not realize his own shortcomings; rather he puts the entire blame of his failures upon his wife, Shirin, who is committed to her, and does not resist to him like a typical rural woman of Pakistan. The setting of the story locates the rural area of the Punjab province of Pakistan. Ghulam Qadir gives different labels to her and one of the harsh label he uses against Shirin is Devil. This term reveals the psyche of Ghulam Qadir who conceives his wife as a sign of bad happenings, murders her, and commits suicide in the end. The very term, foremost, reflects the inmost of the Pakistani rural men who hold absolute power in the family and misuse the religious and cultural norms just in order to extend their long established hierarchical structure where woman is mere a subject to them. This study reveals that males of the rural areas of Pakistan express their psychological frustration over women and allege them by taking refuge under the umbrella of religion.

Keywords: gender roles, religious/ cultural manipulation, power abuse, marriage.

\section{Introduction:}

Whoever works righteousness, man or woman, and has faith, verily to him/her will we give a life that is good and pure, and we will bestow on such their reward according to the best of their actions. ${ }^{1}$

This paper aims to analyze the manipulation of religious and cultural norms by the male members of the society in order to overcome their own shortcomings and how they project their shortcomings into others to overcome their lack with the help of close reading of the story titled The Bull and the She Devil. ${ }^{2}$ The major concerns of the paper are the manipulation of religious and cultural norms to control women, the blame game as cover up for males' own shortcomings in a domestic setup and marriage

\footnotetext{
*Assistant Professor, Dept. of Humanities, COMSATS, University, Islamabad.

Email: doctor.amna9@gmail.com

** Research Scholar, COMSATS, University, Islamabad.

*** Chairman Department of English, Kohat University of Science \& Technology, Kohat.
} 
as a religious/cultural tool to control women.

The cultural interpretations of religion generally assign women as the gatekeepers of modesty and family values by men. ${ }^{3}$ In patriarchal society of Pakistan, males manipulate religion, politics and cultural norms to control women especially those suffering from lower socio-economic conditions. ${ }^{4}$ Marriage is one of the most common ways in Pakistani society for men to assert their power over women. The submissiveness of women is a religiously provoked norm. The equality or dominance of women is not considered as positive in Pakistani society. Men often blame women for their own deficiencies to be on safe side in a marriage. Moreover, in rural areas, the women often become victims in the name of devil possession if they want to add their decisive choices for/in a marriage. ${ }^{5}$

The position of women in Pakistani society has always been a controversial topic. Men in the Pakistani society have suppressed women through politics, religion, marriage, and societal customs of day to day life. "In both rural as well as urban society, Pakistan remains rigidly a patriarchal society, in which women are treated as chattels, 'given' or 'acquired' through arranged marriages to spend their lives in the service of a male dominant system." Marriage is one of the major sources to control women in the patriarchal setup of Pakistani society. The Biraadri (Punchaayat) has an influential function in the rural areas of Pakistan. The male members of the Biraadri normally set norms and regulations for women majorly in the name of religion. These norms and regulations are supported by religious concepts and their opposition has a negative perception in the society. Role of women has been submission to serve as a commodity and to sacrifice herself for the sake of values." Women are controlled by certain restrictions in Pakistani society. For example, in religion " a woman's inheritance is her own, to be spent as she wants; a man's duty is to use his inheritance to support his family" 20 but in our society out of family marriages are avoided in order to sustain the sharing of ancestral land as well as religious sect. Therefore, it becomes difficult for women to live by their own choice. Men are seen to make women responsible for any and every faulty thing. Hence, the system, which has been established since long, mostly protects the control and authority of men by manipulation of religious norms and keeps women away from actively taking political or social roles in society. ${ }^{8}$

Zeb Un Nissa Hamidullah launched Pakistan's first weekly for women in English, The Mirror of the Month, in 1957. She is considered to be one of the pioneers of Pakistani Literature, Journalism in English, and feminism. Her short story The Bull and the She Devil was published in her anthology of short stories The Young Wife and Other Stories (2008). The setting of her story takes place in the Punjab province of Pakistan. ${ }^{9}$ The main character of the story is a man named Ghulam Qadir who is initially a peasant-natured man. Ghulam Qadir marries Shirin three months ago, but he is not satisfied with his marriage life. He thinks that his wife treats everyone nicely except him. He considers her as his enemy and calls her devil. One day, when he goes unable to control his anger, he kills his wife, brother, and nephew to death and commits suicide at the end. 


\section{Research Questions:}

1) How is husbands' lack/inferiority projected in/onto the wife and to what consequences in Pakistani society it leads as depicted in the short story The Bull and the She Devil?

2) How is religion misused to control the women in patriarchal society of Pakistan with reference to the selected story?

\section{Religious and Cultural Manipulation of Gender Roles:}

Islam, as a religion, is one of the only religions that gives women rights, equality and protection in society. However, many a times due to many cultural misinterpretations women get neglected of their rights and protection by the family and the society. ${ }^{10}$ In the law of Allah, men and women are equal, they perform same prayers and rituals and they get rewarded or punished equally:

For Muslim men and women, for believing men and women, for devout men and women, for true men and women, for men and women who are patient and constant, for men and women who humble themselves, for men and women who give in Charity, for men and women who fast (and deny themselves), for men and women who guard their chastity, and for men and women who engage much in Allah's praise, for them has Allah prepared forgiveness and great reward. ${ }^{11}$

However, the rights and responsibilities assigned to men and women regarding family are different but in no way unequal. In fact Allah protects women in their rights in a marriage since the status of motherhood is awarded as the supreme gateway to heaven for the children. It is mandatory for men to pay mehr to wives to ensure their financial support. Even a widow/divorced woman is to be protected/housed by men of the family. In a marriage men are the providers and supporters of women.

Men are the protectors and maintainers of women, because Allah has given the one more (strength) than the other, and because they support them from their means. ${ }^{12}$

The responsibilities given to men in marriage include protection of women and providing them with all their basic needs, like food, shelter, clothing and so on. And since being a provider requires physical hard work, Allah has blessed (the Arabic word being fazal, meaning blessing of Allah on men) men with physical strength since what they earn has a share for the wife and children. It is a hard duty that Allah has given to man, yet culturally somehow men believe that religion gives them the right to assert their physical power in order to control/dominate women. Allah has given the duty of qawamun to men to provide comfort and peace to women so that they can focus on the rightful upbringing of the children, instead men being victims of their own ego, assert their power on women in form of physical/psychological abuse, not knowing that they will be held answerable for not providing a lovable and protective environment for the wife and children. It is also true that in our society when men tend to fail to overpower their wives they start finding faults with the wives often, as in rural areas, tagging them as possessed by the devils.

Psychologically, most men find it important to control their wives through their strength and want to have a dominating role in a marriage. There are several psycho- 
ogical and social reasons behind male bashing females for their own shortcomings. "Abused wives may be persuaded by their husbands that they are incompetent, hysterical and frigid." 13 The manipulation of power is also quite important in this regard. "A consistent finding in the literature on family abuse is that it seems to occur in the context of psychological exploitation, where abusers use their power to manipulate victims' perception of reality." Andrews \& Brewin found in their study that character logical partner blamed by wives was the result of their husbands being alcoholic, psychopathic and schizophrenic. The domestic violence is also caused by husband's stress due to work pressure..$^{15}$ Bograd also supports the reasons of external stress and transient states such as alcohol or anger for self-blame and partner blame in violent domestic situations. ${ }^{16}$ Control is another theme, which can be observed in cases of domestic violence. Some social researches on control on the opposite gender are done with perspective of feminism and also under the light of patriarchy. According to Friedman, male dominance is a general tendency. ${ }^{17}$ Caine presents an alternate model as opposed to the conservative model about male dominance in society. ${ }^{18}$ The conservative model states the gender roles in a society and specifies some roles for males and females in society. According to this model, males have more important roles which are more difficult to perform such as hunting, fishing, and fighting whereas female's roles are limited to domestic life. They need protection. The model presented by Caine suggests that it is the availability of resources that make male more dominant in the society. A female performs male's roles if she is privileged and has access to the resources as that of men. Therefore, it is the possession of position and resources that makes a gender dominant in the society. Males enjoy their power and authority in the society. The specification of gender roles has supported the psyche of male dominance and in many societies, it is considered as a general tendency. Langness writes a comprehensive note on ritual power and male dominance. ${ }^{19}$ His writing supports the idea that male members of the society enjoy the higher ranks and more power in the society. When males fail to have this dominating image and role in the household, they unconsciously project their own weaknesses upon their wives. The wife becomes the "Mirror" which reflects back to husband and his weaknesses instead of her strength. From this discussion on the standing of males and females in society, it is inferred that the males tend to dominate females because they have been enjoying higher position and the power in society since ages. ${ }^{20}$ Moreover, men in Pakistani society are assigned controlling gender roles on the basis of religion. While nowhere in religion one comes across any claim that men are superior to women but cultural interpretation of religious norms enforces these things in society. It has, thus, grown out to be a common tendency in the psyche of the male that he can dominate whenever he is stressed, frustrated and alone. Most of the societies support male dominance. Due to such conditions males have become addicted to such behavior and most of the domestic violence is caused by this inequality in both genders in the modern globalized world.

\section{Methodology:}

The present study is qualitative in its nature and the short story The Bull and the She 
Devil (2008) is critically analyzed from psychoanalytical feminist perspective through a close reading of the text in the light of Quranic references. Psychoanalytical Feminism asserts that men "have an inherent psychological need to subjugate women" and this psyche is further enhanced by the socio-cultural practices of a society. ${ }^{21}$ Religion is an important cultural institution which asserts certain gender roles/ positions on men and women. Through various events language in the narrative related to the protagonist and his wife, the text is analyzed for cultural and religious manipulation of gender roles of men and women in the light of psychoanalytical feminist theories.

\section{Analysis of The Bull and The She Devil:}

Ghhulam Qadir is the protagonist of the short story The Bull and the She Devil (2008) by Zaib-un-Nisa Hameedullah. ${ }^{22}$ The action/ behavior of the protagonist is analyzed the light of Lacanian notions of psychoanalysis. Lacanian Mirror, Autonomous ego of the protagonist and a societal belief that the women can be controlled by marriage are the core focus of this psychoanalysis. The story is described in a rural setting of Punjab which is the province of Pakistan. The story revolves around Ghulam Qadir who is recently married to Shirin. He has a brother, Gul Mohommed, and a nephew, Allah Wasaya. 'Anxiety has been recognized in psychiatry as one of the most common symptoms of mental disorder.' ${ }^{23}$ There are many clues in the text that the protagonist is suffering from some kind of anxiety and complex. As it can be seen in the lines below that the protagonist seems suffering from anxiety and he is also frustrated. The water has cooled him from outside but not from the inside which represents that there is a bulk of anger and frustration going inside him which correspondingly establishes that his mind is not at calm and peaceful position:

Having quenched his thirst he splashed the remaining contents of the bucket over his face and upon his thick crop of unruly black hair. 'This has cooled me' he told himself, 'cooled me from the outside but not from the inside.' He repeated moodily, staring at his bullock resting in the shade.' 'Then he put the bucket back in its place on the edge of the well and looked down into its depths. His glance was a casual one, but suddenly, like a possessed man, he bent his whole body forward and peered in the darkness below, his eyes glittering with excitement. ${ }^{24}$

The protagonist looks into the well. The mirror serves as Lacanian mirror in this story. Though he himself acts like a possessed/mad person but he reflects his madness in the face of his wife in the well. The Lacanian mirror refers to the establishment of ego in the child through his/her body image in the mirror. In the story, the protagonist looks in the mirror and he sees the face of his wife. He projects his lacks/shortcomings onto that face of his wife and blames her for all his sufferings. The protagonist wants to be the patriarchal master of his wife which is related to the autonomous ego of protagonist. The following lines represent how the protagonist is fantasizing his wife's image in the well instead of his own reflection.

From the depths of the water she stared back at him. Yes, even here on the land she haunted him. He looked like loathing upon her sensitive face, that soft slow smile, those eyes full of tenderness. Almost he could hear her speak. Speak in those soft persuasive 
accents that irritated him so. In a sudden outburst of fury he clenched his first at the lovely face, 'Shaitaan' he shouted. She Devil! She Devil! She Devil!' Frenziedly he picked up a stone and hurled it into the well aiming straight in her eyes. ${ }^{25}$

The game of possession is another important concern for the protagonist. The protagonist wants to be the master of his wife. He thinks that he can possess his wife the way he possess his animal, the bull. But in the later part, when his animal is controlled by his wife, and his brother and nephew have good terms with his wife; he gets jealous of her being at the state of equality. He labels her as devil and calls her possession a demonic one whereas ironically it is the protagonist himself who wants to dominate his wife and wants her to be as submissive as she could be. The protagonist thinks that his wife is like his land or his animal which could be molded easily. He wants his wife to be as fertile as his land is. But when she is not giving her any fruits of her womb, he calls her a devil putting the entire blame on her while ignoring his own shortcomings. 'She's after my soul as well, he shouted. She wants to ensnare men as she has ensnared all others. She Devil!'

Yes, it was for him that she cooked, for him that she worked, for him that she existed, for she was not his woman -she his wife and he her master? Yes he told himself again and again, thrusting angrily at his bull to give full emphasis to his thoughts, he was her master and would force her to bring forth the fruits of her womb, even the fields gave up to him their abundance. 'She Devil!'

The matchmaker plays an important role in brainwashing the protagonist in the story. The matchmaker tells the protagonist that this girl will turn his life upside down. She will obey him in every aspect of life and he will be the sole master of her. The protagonist himself thinks that he will be able to control that woman through marriage. It is the societal belief in protagonists' society that women can be controlled through marriages and submissiveness is a crucial element that is expected from them after marriage. But when they do not act upon on such defined ways for them, they are considered as religiously rebellion and are often labelled as 'Shaitaan'. Hence, males of such societies take support of religion to control over their women.

He recalled her words: 'You are a fortunate man, Ghulam Qaidr.' She had said in her quavering old quavering old tones, 'a very fortunate man. For not only is Shirin as sweet as the scent of champak flowers, but she is as supple as reed and will sway to your slightest wishes for she is a child nurtured into womanhood in an atmosphere of tenderness and affection ${ }^{27}$. The protagonist says that his wife has bewitched his family, the matchmaker and even his animal. His bull does not obey him. His willingness of being a superior master is related to his autonomous ego which is an outcome of societal belief that after marriage, he will control his wife the way he wants to. But contrarily, things go in different direction after his marriage. There takes place a communication gap between his wife and him. He cannot bear her good relations with other on equality basis, therefore, he blames her of bewitching his family and bull. She appears as a threat for his patriarchal autonomous ego which he could not happen to maintain in either way. 'She Devil!' he had thought. 'I'll show her who's the owner 
of bull, I'll show her whose command it obeys'. ${ }^{28}$

Ghulam Qadir feels that his patriarchal power is challenged when his wife finally controls the bull. He is not ready to accept that how come his wife has successfully done the thing that he was failed to accomplish and his temperament instead of appreciating his female's act despises it. Like an obedient and good-natured wife, Shirin does not want any applause and his husband even becomes aggressive. He is neither satisfied with his own actions nor his wife's helping hands can curb his ego. It appears to be a chaotic state of mundane affairs when the rural women are suppressed in both situations: if they do not do their household works, they are badly treated, and on the contrary, if they enjoin with their husbands to resolve the daily affairs, they are again maligned as happens with Shirin. He calls her 'She Devil!' which basically reveals the typical manly nature of the rural men of Pakistan who assume women as sign of negativity and evilness. She is true to her husband and is beloved of him initially but still he names her devil and becomes jealous of her. 'Devil' in Islam is taken as a very negative and dangerous character who always misguides the general humanity whereas in the short story Shirin does nowhere misguide her husband nor she damages to the norms of her society but still she is titled as devil by her husband. Without knowing the complete interpretation of any religious text, one cannot issue any decree against the fellow-beings. Ghulam Qadir in this story repeatedly does it without realizing the actual message of Islam. Men like Ghulam Qadir represent the collective patriarchal authority that mostly prevails in the rural areas of Pakistan where the females are undermined, disrespected, and mistreated while misusing the religious terms as happens in Shirin's case. Thus, the harmony generally in a society and particularly at homes is at great stake; it gets diminished with egoistic acts of males who just want to extend their long-established legacies and take women as granted.

'Faithless creature,' he shouted at the poor, uncomprehending animal. 'Even you have surrendered your soul into this she-devil keeping'. He looked from the animal up at the blazing sun and a strange light came into his eyes. 'She's after my soul as well he shouted. 'She wants to ensnare me as she has ensnared all others. She Devil!'29

When the protagonist is no more able to control over his wife and he loses his control over his animal; he kills his wife, brother and nephew and at the end he himself commits suicide in the same well where he used to watch the face of his wife. The protagonist is following a societal belief of Pakistani rural culture that a man can control woman through marriage. If a wife does not obey his husband or does not act as he thinks then the husband has freedom to manipulate religion and to label her as 'Devil'. The husband can also blame his wife for all his shortcomings. All these societal issues are outcomes of patriarchal mindset where males are taught to control their wives after marriage. Islam primarily teaches to purify one's own head and heart which in Ghulam Qadir's case is amiss. He does not take any bit of time to review his state of mind and actions; rather he is found to go hard and harsh against her wife who does her best to satisfy her husband. The protagonist in the story is obsessed with this mindset. He starts fantasizing the face of his wife in the well and starts calling her a 
devil. This results as the death of everyone.

\section{Conclusion:}

The Bull and She Devil depicts typical psyche of rural Pakistani men who are never at peace in their married life. Their psychology, which has been nurtured since centuries, instigates them to use their manly power over their silent, submissive women. Ghulam Qadir married Shirirn some months ago. His patriarchal imaginations made him dream about being the master of his wife. He thought before marriage that he will control his wife the way he wants. He will be the master and everything will obey him including his bull and his wife. "The face of his wife in the well" and the word "Shaitaan (devil)" has symbolic nature in the story. He is not enjoying the authority which he imagined in his patriarchal fascination. That is why he fantasizes the face of his wife in the water of well and projects all blame to that face. He also calls her "Shaitaan" which shows his manipulation of religion to overcome his personal shortcomings. Therefore, the character of Ghulam Qadir takes refuge under the umbrella of religion and also takes support from cultural norms to project his shortcomings over his wife. He blames his wife and the matchmaker instead of realizing his own lack of compatibility in his marital life. There is an influence of patriarchy on his perceptions due to which he manipulates religion as well and instead of protecting his house he puts all the blame on his wife because she is not a proper slave of him which according to him she is supposed to be. it shapes the thought that males of Pakistani rural patriarchal setup have an inbuilt habit that they can control their women by marriage and as it can be seen in the story that if a woman does not serve his husband like a slave, then her husband can label her with any bad titles he knows as in this story he calls her "Shaitaan (devil)". Males of such rural societies, like the Pakistani rural society in the story's context, usually project their own shortcomings into females. It is easier for them to blame female for their own inefficiencies and this blaming can go to an intense extent as the character of Ghulam Qadir blames his wife instead of acceding that he cannot control the bull. As a result, Ghulam Qadir kills his wife in order to satisfy his own lack. Such maltreatment by patriarchal males of the Pakistani rural men design the idea that religious values particularly in rural areas are largely ignored. This way, an idea comes to the forth that Muslim women and especially those of the rural ones are like outsiders in their own society where the psyche of the male members do not seem to adopt and appreciate the positive role of the females. Hence, the analysis of the short story 'The Bull and She Devil' along with stressing the need for revisiting the male psyche also concretizes the need for redefining the religious terminologies so that the men cannot subjugate women anymore by misusing the religious terms without analyzing the contexts of the terms.

\section{References:}

\section{${ }^{1}$ AlQuran, 16:97}

${ }^{2}$ Hameedullah, Zeb-Un-Nisa, "The Bull and the She Devil in The Young Wife and Other Stories, (Oxford: Oxford University Press, 2008). 
${ }^{3}$ Davids, Nuraan, "Religion, culture, and the exclusion of Muslim women: on finding a reimagined form of inclusive-belonging." Knowledge Cultures 4, no. 4 (2016): 46-59.

${ }^{4}$ Ullah, Sana, and Arab Naz, "The Implication of Patriarchy and Gender Roles Socialization on the Socio-Economic Status of Women, in District Dir Upper" Pakistan Journal of Society Education and Language 3, no. 1 (2017): 32-53

${ }^{5}$ Saigol, Rubina, "Women's Empowerment in Pakistan: A Scoping Study". (Aurat Publication and Information Services Foundation, 2011).

${ }^{6}$ Alavi, Hamza, "Pakistani Women in a Changing society." In Economy and Culture in Pakistan, (London: Palgrave Macmillan, 1991): 124-142.

${ }^{7}$ Ali, Parveen Azam, and Maria Irma Bustamante Gavino, Violence against women in Pakistan: A Framework for Analysis." Journal-Pakistan Medical Association 58, no.4 (2008): 198

${ }^{8}$ Qadir, Samina Amin, and Fakhira Riaz, "Gendered Political Identity Construction in Pakistani Television Talk Shows." FWU Journal of Social Sciences 9, no. 1 (2015): 20-28

${ }^{9}$ Imtiaz, Sana, "" Antara or Majnun?"-Exploring Femininities and Sexualities in Zaib-un-Nissa Hamidullah's The Bull and the She Devil." Language in India 12, no. 1 (2012)

${ }^{10}$ Power, Carla. "If the Oceans Were Ink: An Unlikely Friendship and a Journey to the Heart of the Quran", (New York: Holt Paperbacks, 2015)

${ }^{11}$ Alahzab,33:35

${ }^{12}$ Alnisa, $4: 34$

${ }^{13}$ Walker, Lenore E, "The battered woman." (New York: Harper \& Row, 1979)

${ }^{14}$ Finkelhor, David, "Common Features of Family Abuse." The Dark Side of Families: Current Family Violence Research (1983): 17-28

${ }^{15}$ Andrews, Bernice, and Chris R. Brewin, "Attributions of Blame for Marital Violence: A study of Antecedents and Consequences." Journal of Marriage and the Family 52, no. 3 (1990): 757-767

${ }^{16}$ Bograd, Michele, "Power, gender, and the family: Feminist Perspectives on Family Systems Theory" Feminist Psychotherapies: Integration of Therapeutic and Feminist Systems (1988) 118

${ }^{17}$ Friedman, Marilyn, "Autonomy and Male Dominance." Soundings: An Interdisciplinary Journal 87, no. 1/2 (2004): 175-200

${ }^{18}$ Caine, T. Allen, and Christy A.H. Caine, "The Evolution of Male Dominance." Dialectical Anthropology 4, no. 1 (1979): 21-31

${ }^{19}$ Langness, Lewis L, "Ritual, Power, and Male Dominance." Ethos 2, no. 3 (1974): 189-212

${ }^{20}$ Hakim, Abdul, and Azra Aziz. "Socio-cultural, Religious, and Political Aspects of the Status of Women in Pakistan." The Pakistan Development Review 37, no. 4 (1998): 727-746

${ }^{21}$ Wolff, Kristina, "Psychoanalytic Feminism", (Wiley Online Library, 2007)

${ }^{22}$ Hameedullah, Zeb-Un-Nisa, "The Bull and the She Devil in The Young Wife and Other Stories, Oxford: Oxford University Press, 2008

${ }^{23}$ Evans, Dylan, An Introductory Dictionary of Lacanian Psychoanalysis, (Routledge, 2006

${ }^{24}$ Hameedullah, Zeb-Un-Nisa, "The Bull and the She Devil in The Young Wife and Other Stories

${ }^{25}$ Ibid

${ }^{26}$ Ibid

${ }^{27}$ Ibid

${ }^{28}$ Ibid

${ }^{29}$ Ibid

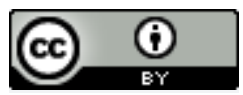

This work is licensed under a Creative Commons Attribution 4.0 International License. 